\title{
Intermediate Fibroblastic Neoplasm
}

National Cancer Institute

\section{Source}

National Cancer Institute. Intermediate Fibroblastic Neoplasm. NCI Thesaurus. Code

C7333.

A locally aggressive or rarely metastasizing neoplasm that arises from the soft tissues. It

is characterized by the presence of neoplastic spindle-shaped fibroblasts. 